\title{
Contribution of the Mutis Timau Protected Forest to Community Income in the Forest Management Unit of South Central Timor Regency, Timor Island, Indonesia
}

\author{
Fransiskus Xaverius Dako ${ }^{1}$, Ris Hadi Purwanto ${ }^{2 *}$, Lies Rahayu Wijayanti Faida ${ }^{3}$, Sumardi $^{4}$
}

\begin{abstract}
${ }^{1}$ Department of Forestry, Politeknik Pertanian Negeri Kupang, Jl. Prof. Herman Johanes, Lasiana, Kupang, Indonesia 85011 ${ }^{2}$ Department of Forest Management, Faculty of Forestry, Universitas Gadjah Mada, Yogyakarta, Indonesia 55281

${ }^{3}$ Department of Forest Resource Conservation, Faculty of Forestry, Universitas Gadjah Mada, Yogyakarta, Indonesia 55281

${ }^{4}$ Department of Silviculture, Faculty of Forestry, Gadjah Mada University, Yogyakarta, Indonesia 55281
\end{abstract}

Received March 17, 2019/Accepted June 30, 2020

\begin{abstract}
Communities in and around the forest always interact and use the resources to satisfy their daily needs for survival. Forest resources obtained by the community are used to satisfy family needs, and one is an additional family income. This study aimed at determining the contribution of Mutis Timau protected forest to community income. In order to knowing the income that the community earns from the forest, a survey was conducted in nine villages located in and around Mutis Timau protected forest that started from January to June 2018. Nine villages were purposively selected that Mutis Timau protected forest area is administratively under those villages whose communities directly interact with the protected forest. The technique of collecting data was a questionnaire with 353 respondents selected proportionally in each village. Also, observation and literature study were adopted. The data were descriptively analyzed. The results denote that Mutis Timau protected forest provide income to the community through non-timber forest products of IDR1,637,510,566 year ${ }^{-1}$ of the total income of IDR45,260,686,262 year-1. Community income earned from Mutis Timau protected forest is very low (3.62\%) compared to the income gained from horticultural food crops $(66.29 \%)$ and livestock (30.09\%). The income is directly earned from the sale of non-timber forest products to the consumers without having product processes in particular for hunting wild animals, fungus, tubers, and honey. Honey delivers higher income besides other non-timber forest products, such as hunting wild animals, fungus, and tubers.
\end{abstract}

Keywords: protected forest, community income, non-timber forest products, Mutis Timau

*Correspondenceauthor,email: rishadi@ugm.ac.id

\section{Introduction}

Mutis Timau Protected Forest (MTPF) area is a mountain forest group located in the forest management unit (FMU) of South Central Timor Regency in East Nusa Tenggara Province. As a large group of mountain forests, it is often referred as the lung of Timor island. Many advantages and contributions are directly gained from MTPF existence to the communities around and within the protected forest areas, mainly fresh air, water, ecotourism (beautiful natural panorama), carbon sinks, firewood, carpentry wood, and income earned from non-timber forest products (NTFPs).

NTFPs supplied from forest resources get much attention in conservation circles (Ticktin, 2004). NTFPs management has increased over the last few decades that globally concerns about rural poverty, deforestation, which is later adopting the concept of sustainable development (Belcher \& Perez., 2005). NTFPs are used for cultural and recreational purposes and deliver various opportunities, including cultural preservation, forest biodiversity support, and rural economic development (Kar \& Jacobson, 2012). NTFPs are considered as more important values in household cash income (Roe \& Naughton-treves, 2014; Mahapatra et al., 2015; Uprety et al., 2016; Liu et al., 2018) and as a household economic safety net (Mutenje et al. 2011). Overall, NTFPs income is much higher than the income gained from wood or firewood (Kar \& Jacobson, 2012). In addition, the subsistence household income of the poor is relatively more dependent on NTFPs (Kar \& Jacobson, 2012). NTFPs are important sources for millions of people's income in tropical forest areas (Turjaman et al., 2006). The potential NTFPs play a role in improving nutrition, health, and reducing poverty (Ahenkan \& Boon, 2011). Rural farmers living near protected areas receive cash subsistence income from forest-based activities, mainly from forest products collection (McElwee, 2010).

Communities living in and around protected forest areas depend highly on natural resources (Liu et al., 2010). Community interaction in MTPF is to suffice household 
needs by exploring the utilization of NTFPs, firewood, carpentry wood, and income earned from NTFPs. Forest resources from the MTPF in the form of firewood are used for household energy needs (Dako et al., 2018), while NTFPs are used for either consuming or selling to fulfill household needs. NTFPs supplied by MTPF are used by the communities for household needs, such as income earned from hunting wild animals (jungles, wild boar, deer, cuscus, birds, ferrets, and other wild animals), fungus, tubers, and honey. However, information about sufficing household needs deals with NTFPs income earned from MTPF is unknown yet. In their daily life, communities always utilize and sell these NTFPs. So far, people's income source around the forest is earned from agricultural products, livestock, and businesses, in which they do not calculate the income gained from protected forests in terms of NTFPs. Therefore, there is a lack of information about NTFPs income. The gap encourages the researchers to find out the incomes gained from MTPF and its contribution to the income of people living in and around the protected forest. This paper focuses on the discussion of income earned from protected forests in terms of NTFPs utilized by the community including hunting wild animals, fungus, tubers, and honey.

\section{Methods}

Research location The research was conducted in nine villages located in and around the MTPF area, at the FMU of South Central Timor Regency, Timor Island. The study has purposively selected the villages considering that MTPF was administratively controlled by these nine villages. The research was conducted for six months, from January to June
2018. The research location is shown in Figure 1.

Data collection and analysis This study utilized survey with descriptive analysis to meet the objective. The research method focused on solving the present problems, while the problems solved were factual problems (Nazir, 2003) with quantitative and qualitative approaches. The population of the study was the head of each family. The sampling technique to get respondents was referred to Slovin Formula (Sevilla et al. 1993) with a tolerable error limit of $5 \%$ as shown in Equation [1].

$n=\frac{N}{1+N e^{2}}$

note: $\mathrm{n}=$ number of samples; $\mathrm{N}=$ total of population; $\mathrm{e}=$ tolerable error limit (5\%)

Furthermore, the number of samples in each village is proportionally calculated with the equation as shown in Equation [2].

$n d=\frac{T P}{T P d} \times n$

note: $n d=$ sample for each village; $\mathrm{n}=$ total number of samples; TPd $=$ total village of population; $\mathrm{TP}=$ total of population.

Thereby, the study respondents were 353 of 3,004 households spread proportionally in each village based on the number of households (Table 1).

Data collected in the study were primary data and secondary data. Primary data was community income earned

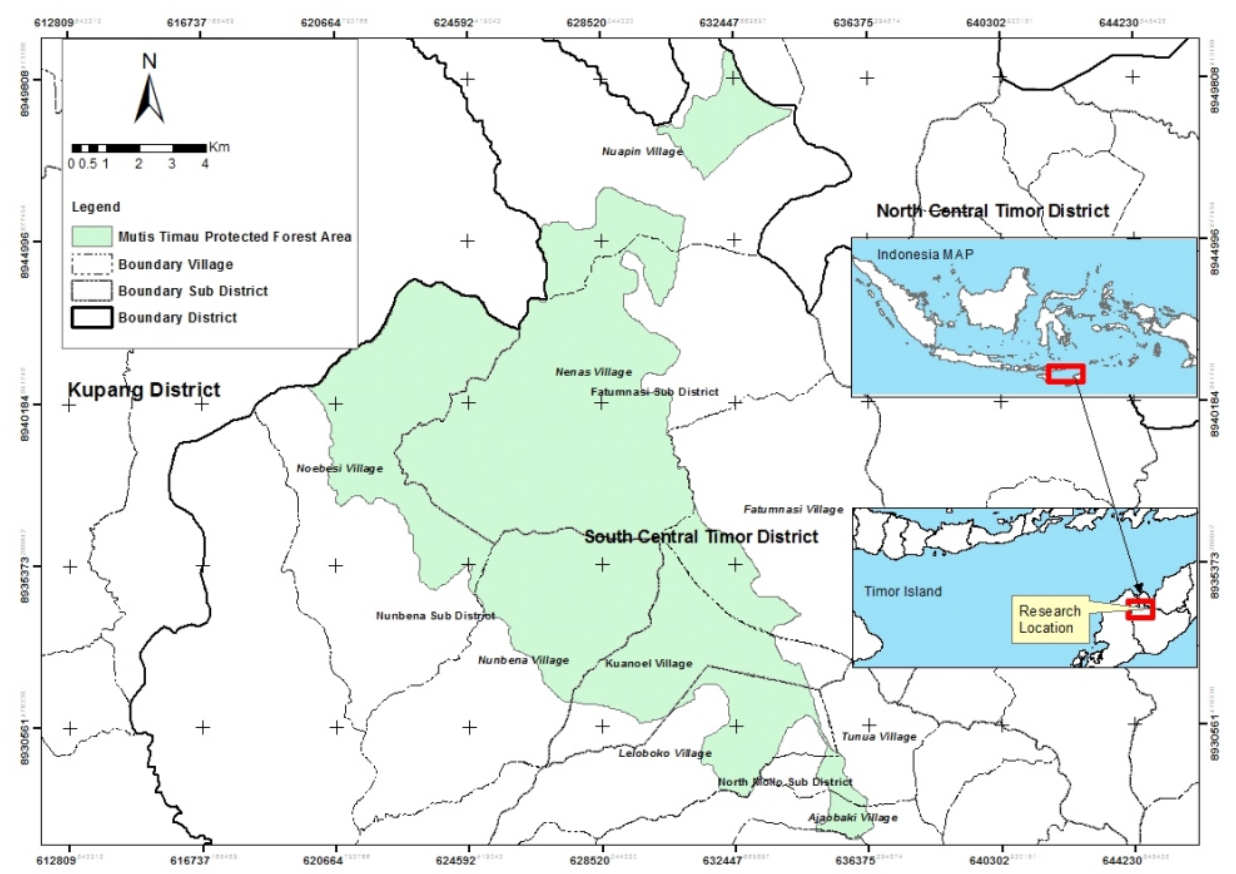

Source: Dako et al. (2019)

Figure 1 Map of the research location. 
Table 1 Number of respondent samples in each village

\begin{tabular}{lccc}
\hline Villages & $\begin{array}{c}\text { Population } \\
\text { number }\end{array}$ & $\begin{array}{c}\text { Number of } \\
\text { house hold }\end{array}$ & $\begin{array}{c}\text { Number of } \\
\text { house hold } \\
\text { sample }\end{array}$ \\
\hline Nunbena & 894 & 221 & 26 \\
Noebesi & 1,378 & 300 & 35 \\
Leloboko & 781 & 193 & 23 \\
Tunua & 1,798 & 421 & 50 \\
Ajaobaki & 1,893 & 407 & 48 \\
Nuapin & 2,249 & 454 & 53 \\
Nenas & 1,230 & 267 & 31 \\
Kuanoel & 1,231 & 316 & 37 \\
Fatumnasi & 1,589 & 425 & 50 \\
\hline Total & 13,043 & 3,004 & 353 \\
\hline
\end{tabular}

from food crops and horticulture, livestock, and NTFPs supplied by MTPF. Secondary data collected consisted of village monographs, research reports, journals, and other documents that support the research. Data collection of the study used interviews with questionnaires, observations, and literature studies.

In this study, community income was calculated by enlisting the amount of income in 2017 (one year). Diniyati \& Ahmad (2015) argues that the income earned by farmers is income in the previous year. The income is measured by multiplying price and activity results (agricultural and forestry products) (Simon 2010). Food crop income from horticulture is in the form of farming income. Andayani (2005) argues that farming income is an economic value of commodities cultivated during the period of analysis, including annual crops (food, horticulture, and various kinds of crops), perennials (wood, fruit, and plantations), and livestock. Income from other sectors is earned from side jobs, such as laborers, craftsmen, forest product collection, etc while income from livestock is in the form of livestock business, and income from the forest is by selling NTFPs. In this study, respondents' income is earned from food crops and horticulture, livestock, and NTFPs. The formula used to calculate the total of household income is a modification from Diniyati \& Ahmad (2015) as shown in Equation [3].

$\mathrm{Prt}=\mathrm{Ptph}+\mathrm{Ppt}+\mathrm{Pht}$

note: Prt $=$ total of household incomes $\left(\right.$ IDR year $\left.{ }^{-1}\right) ;$ Ptph $=$ income from food crops and horticulture (IDR year $\left.{ }^{-1}\right) ; \mathrm{Ppt}=$ income from the livestock sector $\left(\right.$ IDR year $\left.{ }^{-1}\right)$; Pht $=$ income from the protected forest (IDR year ${ }^{-1}$ )

The limitation of the research is income contribution earned from the MTPF area in the form of NTFPs sale (hunting wild animals, fungus, tubers, and honey) that the communities do so far. Hunting wild animals, fungus, and tubers are sold directly door to door during the harvest season or at the weekly market in the capital of the sub-district without following market prices. Whereas, honey, sold directly during harvest time, is also sold daily in front of the communities' houses. These products are often sold under market prices. The community income from MTPF is the real (factual) income obtained by the community in the research location when selling NTFPs. The income contribution from MTPF is the income contribution that includes NTFPs, such as hunting wild animals, fungus, tubers, and honey, to community income. The contribution of the forestry sector to the total of community income uses the formula as shown in Equation [4] (Diniyati \& Ahmad 2015).

$\mathrm{KR}=\frac{\mathrm{Pht}}{\mathrm{Prt}} \times 100 \%$

note: $\mathrm{KR}=$ income contribution from protected forests $(\%)$; $\mathrm{Pht}=$ income from the protected forest $\left(\right.$ IDR year $\left.{ }^{-1}\right) ; \mathrm{Prt}=$ total of household income (IDR year ${ }^{-1}$ )

The tabulation results of income data from MTPF is then analyzed descriptively and qualitatively to get a clear explanation of the research problems.

\section{Results and Discussion}

Characteristics of respondents The survey respondents were 353 people living in and around MTPF. Proportionally, they were distributed in nine sample villages, and $97.17 \%$ were local, while $2.83 \%$ were immigrants. The term of immigrants refer to the situation where the household head (husband) adopted and stayed with his wife's family under Timorese marital status. The people who live in the MTPF region are mostly Dawan tribes. The Dawan tribe is an indigenous tribe of West Timor, Timor island. In general, respondents and people interact with each other using the Dawan language, and with outsiders, they use the Indonesian language to maintain the Timorese (Dawan) culture.

Respondents rely on slash-and-burn farming systems to meet daily needs. They are primarily dominated by a range of farmers' farming activities, such as various vegetables, upland rice, tubers, nuts, fruits and vegetables, and household-scale plantings such as oranges and avocados mangoes, and coffee. In addition to farming, they also have animals, such as cows, horses, goats, and sheep. They take NTFPs from the MTPF area, such as hunting wild animals (e.g., jungles, wild boar, deer, cuscus, and other wild animals), taking forest fungus during the rainy season, forest tubers, and forest honey produced by bees. Forest honey supplied by MTPF and the Mutis nature reserve on the Mutis Mount is known to be pure honey. The Mutis honey, with eucalyptus flowers as the main sources, is acknowledged has the highest quality honey, not only in the island of Timor, but also in Indonesia.

Overall, the main livelihoods of respondents are $100 \%$ as farmers. The respondents living in and around the MTPF area extremely dependent on agricultural land. Respondent's agricultural land area varies from one respondent to another. Respondents of land area $<0.5$ ha $17 \%, 0.5-1$ ha is $76.5 \%$, and $>1$ ha is $6.5 \%$ (Dako et al. 2019). The education level of most respondents is elementary school. The data confirm that the respondents' education level is that primary school is $73.9 \%$, junior high school is $14.7 \%$, and senior high school is $11.3 \%$. In terms of gender, most respondents are male, with $89 \%$ and females with $11 \%$ (Dako et al., 2018). The female respondents in this study are the household heads whose husbands are dead. These women take over the role of fulfilling their household daily needs.

Contribution of the MTPF to community income MTPF, as one of the protected forest areas on Timor Island in the West Timor, has high diversity, such as types of timber forest 
products, NTFPs, environmental services, and ecotourism. MTPF also contributes to the community referring to the income of people who are living in and around the forest area. The research results in nine villages in and around MTPF show that a total of respondents' income is IDR 5,316,852,170 year ${ }^{-1}$, and overall, a total of community income is IDR45,260,686,262 year $^{-1}$. The highest community income is in Fatumnasi Village, and the lowest is in Leloboko Village. The income earned comes from food crops and horticulture, livestock, and NTFPs. This total income posture greatly influences the income per capita in each village since an average of all villages is IDR3,398,044.72 year $^{-1}$.

The community's income is dominantly derived from food crop and horticultural commodities, livestock, and protected forests. Community income earned from food crops and horticulture is $66,29 \%$, livestock is $30,09 \%$, MTPF is $3,62 \%$. The total income in nine villages is IDR 45,260,686,262 year ${ }^{-1}$ with distribution of food crops and horticulture is IDR30,003,279,076 year $^{-1}$, livestock is IDR13,619,896,621 year $^{-1}$, and MTPF is IDR1,637,510,566 year $^{-1}$ (Table 2 and Figure 2). Income contribution derived

Table 2 Community income in and around the MTPF

\begin{tabular}{|c|c|c|c|c|c|c|c|c|}
\hline \multirow{2}{*}{ Village } & \multirow{2}{*}{$\begin{array}{l}\text { Number of } \\
\text { respondent }\end{array}$} & \multicolumn{4}{|c|}{ Respondent income (IDR year ${ }^{-1}$ ) } & \multirow[b]{2}{*}{ Mean } & \multirow{2}{*}{$\begin{array}{l}\text { Total village } \\
\text { income } \\
\left(\text { IDR year }{ }^{-1}\right)\end{array}$} & \multirow{2}{*}{$\begin{array}{l}\text { Income per } \\
\text { capita per } \\
\text { year } \\
(\text { IDR year-1) }\end{array}$} \\
\hline & & $\begin{array}{c}\text { Food \& } \\
\text { horticulture }\end{array}$ & Livestock & $\begin{array}{l}\text { Protected } \\
\text { forest }\end{array}$ & Total & & & \\
\hline Nunbena & 26 & $175,930,050$ & $86,200,000$ & $33,900,000$ & $296,030,050$ & $11,385,771$ & $2,516,255,425$ & $2,814,603$ \\
\hline Noebesi & 35 & $365,085,000$ & $78,850,000$ & $47,360,000$ & $491,295,000$ & $14,037,000$ & $4,211,100,000$ & $3,055,951$ \\
\hline Leloboko & 23 & $145,775,000$ & $68,980,000$ & $10,735,000$ & $225,490,000$ & $9,803,913$ & $1,892,155,217$ & $2,422,734$ \\
\hline Tunua & 50 & $637,615,000$ & $125,795,000$ & $14,300,000$ & $777,710,000$ & $15,554,200$ & $6,548,318,200$ & $3,642,001$ \\
\hline Ajaobaki & 48 & $549,616,000$ & $254,980,000$ & $4,250,000$ & $808,846,000$ & $16,850,958$ & $6,858,340,042$ & $3,623,001$ \\
\hline Nuapin & 53 & $545,397,000$ & $254,166,620$ & $15,070,000$ & $814,633,620$ & $15,370,446$ & $6,978,182,330$ & $3,102,793$ \\
\hline Nenas & 31 & $305,197,000$ & $187,050,000$ & $40,360,000$ & $532,607,000$ & $17,180,871$ & $4,587,292,548$ & $3,729,506$ \\
\hline Kuanoel & 37 & $400,513,500$ & $129,650,000$ & $12,460,000$ & $542,623,500$ & $14,665,500$ & $4,634,298,000$ & $3,764,661$ \\
\hline Fatumnasi & 50 & $400,612,000$ & $413,620,000$ & $13,385,000$ & $827,617,000$ & $16,552,340$ & $7,034,744,500$ & $4,427,152$ \\
\hline Total & 353 & $3,525,740,550$ & $1,599,291,620$ & $191,820,000$ & $5,316,852,170$ & $131,400,999$ & $45,260,686,262$ & $30,582,403$ \\
\hline Mean & & $391,748,950$ & $177,699,068$ & $21,313,333$ & $590,761,352$ & $14,600,111$ & $5,028,965,140$ & $3,398,045$ \\
\hline
\end{tabular}

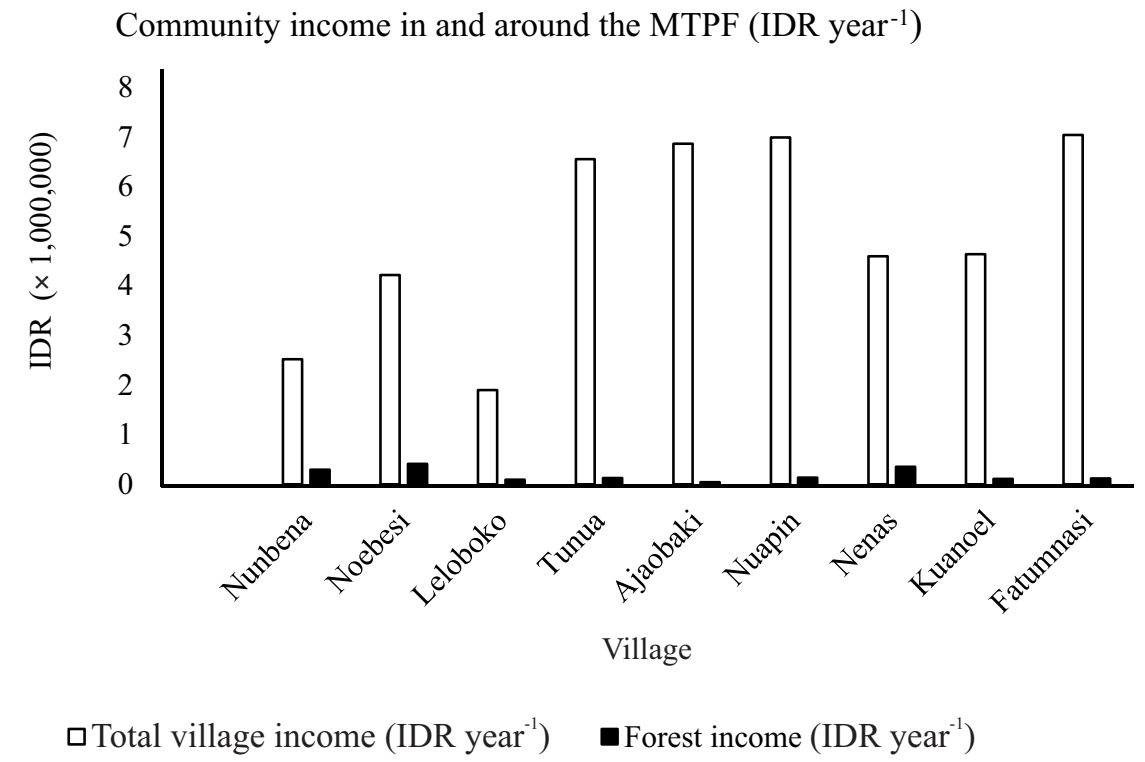

Figure 2 Community income in and around the MTPF. 
from food crops and horticulture is greater than livestock and forests because the most dominant community jobs are farmers, relying on agricultural production. Income derived from food crops and horticulture is corn production, cassava, sweet potatoes, peanuts, tourist beans, green beans, oranges, bananas, mangoes, and avocados. As a dominant area of harvesting corn, the main income source is corn production. The income obtained from each sampling village is various and depends on the village located. Villages that have a height $>900 \mathrm{~m}$ asl with high rainfall, contribute more than $10 \%$ of overall total income. High rainfall supports the community to cultivate their yards and gardens to plant vegetables, carrots, leeks, garlic, celery, potatoes, and other types. The above commodity provides a significant additional income for the community. While in villages that are $<900 \mathrm{~m}$ asl, the community only relies on income from livestock, NTFPs from protected forests, and food crops without planting vegetables. In terms of land area, $95.1 \%$ of respondents own land $>0.5$ ha, but the communities always utilize available forest resources in MTPF for socio-cultural interests. The second-largest contribution to all respondent income is by selling livestock. Various livestock raised by the community are cows, buffaloes, horses, goats, pigs, dogs, and chickens. However, only chickens, cows, and pigs that commonly provide additional income because the community majorly raises these types of livestock.

In this article, the main discussion is the contribution of MTPF as an additional income of people living in and around the forest. The contribution of MTPF to the total income of the community: Nunbena is $0.63 \%$, Noebesi is $0.89 \%$, Leloboko is $0.20 \%$, Tunua is $0.26 \%$, Ajaobaki is $0.07 \%$, Nuapin is $0.28 \%$, Nenas is $0.75 \%$, Kuanoel is $0.23 \%$, and Fatumnasi is $0.25 \%$ (Table 2). While MTPF contribution to the total income of nine villages: Nunbena is $11.45 \%$, Noebesi is $9.63 \%$, Leloboko is $4.76 \%$, Tunua is $1.83 \%$, Ajaobaki is $0.52 \%$, Nuapin is $1.84 \%$, Nenas is $7.57 \%$, Kuanoel is $2.29 \%$, and Fatumnasi is $1.61 \%$. The income structure in each village is not great among communities because dominant income sources are relatively obtained from agriculture, hunting wild animals, and protected forest. Various income contributions from the MTPF depend on various types of plant, land area, production yield, technology, and human resources (respondents) in optimizing to utilize NTFPs. If human capital in each village is equal, then income inequality will be less. Otherwise, if human capital is not equal, income inequality will be greater. Mahmood \& Zaleha (2013) argue that human capital inequality has a significant positive effect on income inequality.

The income earned from NTFPs is by selling hunting wild animals, forest mushrooms, forest tubers, and forest honey (Table 3). The income contribution obtained from hunting wild animals, mushrooms, forest tubers, and honey to total NTFPs in the whole study area is respectively $33.72 \%, 1.72 \%, 1.41 \%$, and $63.13 \%$. The income contribution from honey is relatively higher than other NTFPs because production results and sale prices are high enough. At present, honey is traditionally produced. If honey management applies modern technology, the sale price may be higher. It also affects the overall income earned from MTPF. In Tunua and Ajaobaki villages, community income is not earned from honey because they do not have beehives that produce honey. The next most significant contribution to NTFPs income is hunting wild animals, including partridge, wild boar, birds, deer, etc. Some of the hunting products are either sold or eaten. In tropical forests, hunted meat is the choice and the only source of protein for human (Junior et al., 2010). However, hunting carries a paradox for biodiversity conservation and is a problem as well as solution for species decline and poverty (Petriello \& Stronza, 2019).

Similarly, forest mushrooms and bulbs are directly sold with lower market price. When the forest tubers and mushrooms are processed and packaged properly, the sale price will be higher. This factor is caused by the low formal education level of the community, contributing to their knowledge of processing honey, mushrooms, and forest tubers. Low knowledge of processing forest products will create a temporal decision to earn money rather than how to

Table 3 NTFP income contribution from MTPF in each village

\begin{tabular}{|c|c|c|c|c|c|c|c|c|}
\hline \multirow{2}{*}{ Villages } & \multirow{2}{*}{$\begin{array}{l}\text { Altitude } \\
\text { (m asl) }\end{array}$} & \multicolumn{4}{|c|}{ NTFP's respondent income (IDR year ${ }^{-1}$ ) } & \multirow[b]{2}{*}{ Total } & \multirow[b]{2}{*}{ Mean } & \multirow{2}{*}{$\begin{array}{c}\text { Total income of } \\
\text { NTFP from each } \\
\text { village } \\
\left(\text { IDR year }{ }^{-1}\right)\end{array}$} \\
\hline & & $\begin{array}{l}\text { Hunting wild } \\
\text { animals }\end{array}$ & $\begin{array}{l}\text { Forest } \\
\text { fungus }\end{array}$ & $\begin{array}{l}\text { Forest } \\
\text { tubers }\end{array}$ & Honey & & & \\
\hline Nunbena & 771.54 & $5,500,000$ & 440,000 & 160,000 & $27,800,000$ & $33,900,000$ & $1,303,846$ & $288,150,000$ \\
\hline Noebesi & 500.58 & $11,600,000$ & 400,000 & 260,000 & $35,100,000$ & $47,360,000$ & $1,353,143$ & $405,942,857$ \\
\hline Leloboko & 806.95 & $7,100,000$ & 185,000 & 250,000 & $3,200,000$ & $10,735,000$ & 466,739 & $90,080,652$ \\
\hline Tunua & $1,143.50$ & $13,500,000$ & 310,000 & 490,000 & 0 & $14,300,000$ & 286,000 & $120,406,000$ \\
\hline Ajaobaki & 990.31 & $3,500,000$ & 330,000 & 420,000 & 0 & $4,250,000$ & 88,542 & $36,036,458$ \\
\hline Nuapin & $1,197.35$ & $10,000,000$ & 710,000 & 360,000 & $4,000,000$ & $15,070,000$ & 284,340 & $129,090,189$ \\
\hline Nenas & $1,096.16$ & $4,000,000$ & 200,000 & 160,000 & $36,000,000$ & $40,360,000$ & $1,301,935$ & $347,616,774$ \\
\hline Kuanoel & $1,386.03$ & $4,000,000$ & 250,000 & 210,000 & $8,000,000$ & $12,460,000$ & 336,757 & $106,415,135$ \\
\hline Fatumnasi & $1,519.86$ & $5,500,000$ & 475,000 & 410,000 & $7,000,000$ & $13,385,000$ & 267,700 & $113,772,500$ \\
\hline Total & & $64,700,000$ & $3,300,000$ & $2,720,000$ & $121,100,000$ & $191,820,000$ & $5,689,002$ & $1,637,510,566$ \\
\hline Mean & & $7,188,889$ & 366,667 & 302,222 & $13,455,556$ & $21,313,333$ & 632,111 & $181,945,618$ \\
\hline
\end{tabular}


process the commodity at a better sale price. Income earned from MTPF provides benefits for community lives even though it is in low percentage viewed from an economic aspect.

The explanation above confirms that forest existence has made a real contribution to the community around and in MTPF area in terms of income with different levels. Other studies in different places confirm that the community income contribution gained from protected forest areas to surrounding communities is $52.5 \%$ of total income (Senoadji, 2009). The contribution of forest income to annual household income is 22\% (Vedeld et al., 2007), 32.6\% (Asfaw et al., 2013), 28\% (Angelsen et al., 2014), 20\% (Kaoma \& Shackleton, 2015), 5.8\% (Oli et al., 2016). The income earned from forests is significant for poor households (47.3\%), medium households (30.5\%), or wealthy households (20.2\%) (Asfaw et al., 2013). For very poor households, the income from forest contributes up to $63 \%$ of their total income (Worku et al., 2014). The main sources of forest environment income are firewood, wild food, fodder, dominantly come from state forests.

State forests provide more income than private forests, and $69 \%$ of state forest area is accessed by poor farmers and makes more money than subsistence farmers' income (Jagger at al., 2014). Dewi et al. (2018) draw that state forests in Kulon Progo managed by the community in community forestry have contributed $5.4 \%$ to community income. MTPF, as state forest, contributes income to the community in nine villages as the research location with the contribution of $3.62 \%$. In addition of sold as an additional income, NTFPs are also consumed by communities when they are in starvation. The community tends to sell NTFPs directly from MTPF without having the yield processing that can provide higher income. Loaiza et al. (2015) state that indigenous peoples have a high dependence on forests and environment as well as higher incomes than other community groups. Indigenous people have an important role in maintaining forest resources management and have a close relationship with forests while formulating and implementing forestry policies (Norini \& Fadli, 2007). Forest income plays an important role in reducing the households' income inequality with poor assets and live under the poverty line (Das, 2010).

The income contribution from MTPF is meager compared to other places. MTPF delivers a real influence viewed from economic, social, and ecological aspects. From the economic perspective, the income value is low. Nevertheless, it has, at least, provided additional income for the community. It has a considerable influence in the ecological aspect, such as habitation of organisms, water supply, preventing flood, controlling erosion, oxygen and germplasm sources. In the social aspect, however, MTPF is as a ritual place of social life with local wisdom knowledge. Viewed from the economic aspect, low income is caused by selling at a low price and is not following the mechanism of market prices. The community in and around MTPF even do not know how to precisely calculate selling price. The important thing for them is that the products are quickly sold to make money to suffice basic household needs, such as food, especially for buying rice. The strategy of increasing community income in and around MTPF is an intervention in selling products controlled by market prices and involve the community to utilize the forest area, environmental services, and NTFPs collection through community empowerment (facilitation and assistance) activities with social forestry. Wulandari \& Kurniasih (2019) state that facilitation most preferred by the community is based on entrepreneurship. The main priority of facilitation is individual group members, groups and other villagers, and external facilitators and government staff. Community involvement is in line with government programs to alleviate community poverty and provide access to communities to utilize surrounding forest resources.

The legal community involvement in utilizing forest resources is not merely to increase additional income for four commodities described above. Still, it is to stimulate other activities in producing economically other commodities. Of course, in applying different commodity types, it must be based on the regulation employed, environmental services, and ecotourism. The collection of forest products is regulated in the Forestry Law No. 41 of 1999 and Government Regulation No. 6 of 2007. Community involvement in MTPF management is helpful in improving community welfare, with additional income from different commodities. As a protected forest area, the intervention of empowerment activities that can be adopted in MTPF area are honey bee, mushroom, ginger, turmeric, ornamental plant cultivations. The activities of collecting forest products are rattan, honey, latex, fruit, mushrooms, and bird's nest wallet. The activities of utilizing environmental services and ecotourism are water use, natural tourism, and carbon sequestration.

Community empowerment programs in social forestry are conducted by several schemes, such as community forests, community plantations, village forests, and partnership patterns (Minister of Environment and Forestry Regulation Number 83/2016). The social forestry scheme can directly increase additional community income earned from MTPF and prevent forest damage due to the anthropogenic activities. There is a need of facilitation and assistance in managing NTFPs specifically in technology so that the sale price can be higher, mainly for honey products. At present, honey obtained from the forest is traditionally processed and sold at the price of IDR40,000 liter ${ }^{-1}$ (during data collection) by the farmers in the research location. When the honey is processed in a modern way with a technological approach, the price becomes IDR125,000 liter $^{-1}$ sold in So'E and Kupang. The technical approach in processing honey mentioned here is how to purify honey from waxy layers and other impurities, such as leaves or beehives, by filtering the impurities. Also, honey must be packaged in clean bottles or jerrycans. In fact, when honey is well processed with a technological assistance from related agencies, it will get a three-fold profit compared to the traditionally-honey process. Honey's contribution to income also increases threefold compared to the current contribution. Likewise, other commodities need assistance and facilitation to increase additional value and sale price. Community involvement in and around MTPF through collaboration patterns in forest management is an effort to increase community income and prevent forest damage. Mazunda \& Shively (2015) draw that collaborative programs in forest management can be useful to achieve environmental goals without victimizing household livelihoods. Households participating in forest 
management have higher income levels. They can reduce poverty (Rahut et al., 2015) and significantly increase the local community's livelihoods (Chen et al., 2013).

The Indonesian government, particularly the Indonesian Ministry of Environment and Forestry, through the Ministry of Environment and Forestry Regulation Number 83/2016, has launched a social forestry program that has adhered to the spirit of social forestry principles through several schemes. As a protected forest area, MTPF in its management is encouraged by several social forestry schemes, such as community forests and partnerships. Community forests schemes and partnerships with agroforestry patterns can be useful to increase community income because of the community's active participation and involvement with a spirit of collaboration. Morselo et al. (2012) state that building partnerships can improve NTFPs and local communities' financial results. The agroforestry scheme is applied to recover damaged-protected forest areas and to obtain additional income by selling plantation/annual crops in terms of fruits, environmental services, ecotourism, and NTFPs. The social forestry program requires a strong commitment from the government, especially FMU of South Central Timor Regency as the forest manager at the site level through its pro-community policies to actualize community welfare and forest sustainability. Rahut et al. (2015) argue that government policies must focus on promoting the integrated use of forest resources and forest sustainability to increase rural livelihoods and income.

\section{Conclusion}

The community income in research location covers income from food crops and horticulture, livestock, and NTFPs. The most significant community income comes from food crops and horticulture, and the smallest is from NTFPs. MTPF has provided its benefits to the community by utilizing NTFPs, including hunting wild animals, fungus, tubers, and honey. NTFPs also provide an additional income for the community with income from honey provides a large contribution compared to other NTFPs income. Overall income from NTFPs is small because the results obtained are directly sold without being controlled by market prices and based on current needs. Income from NTFPs can be increased when the government intervention with proper market prices and empowerment programs such as facilitation and assistance to utilize NTFPs with a technological approach. The technological approach in processing NTFPs can provide a higher bargaining position, especially the selling price, which is higher than the direct sales of NTFPs. Increasing the income of communities living in and around the forest can be done in social forestry programs through community empowerment approaches with agroforestry patterns. The social forestry program can provide access to the community to utilize forest areas, environmental services, and ecotourism as well as NTFPs collection. Thus, MTPF delivers its benefits to the community to improve the welfare of the community.

\section{Acknowledgment}

Authors would like to thank the Ministry of Science, Technology, and Higher Education for the opportunity to continue the BUDI-DN Doctoral Education Program and to the Ministry of Finance through the Indonesia Endowment Fund for Education who have provided facilities and services during the research. Also, the most profound gratitude goes to the respondents in Nunbena, Noebesi, Leloboko, Tunua, Ajaobaki, Nuapin, Nenas, Kuanoel, and Fatumnasi, who have given valuable information for the current research.

\section{References}

Ahenkan, A., \& Boon, E. (2011). Improving nutrition and health through non-timber forest products in Ghana. Journal of Health, Population and Nutrition, 29(2), 141-148. https://doi.org/10.3329/jhpn.v29i2.7856

Andayani, W. (2005). Ekonomi pengelolaan hutan rakyat: Aspek kajian pola usaha tani dan pemasaran kayu rakyat, in Kelangkaan air: Mitos sosial dan kiat ekonomi rakyat. Yogyakarta: Debut Press.

Angelsen, A., Jagger, P., Babigumira, R., Belcher, B., \& Wunder, S. (2014). Environmental income and rural livelihoods: A global-comparative analysis. World Development, 64, 12-28. https://doi.org/10.1016/j. worlddev.2014.03.006

Asfaw, A., Lemenih, M., Kassa, H., \& Ewnetu, Z. (2013). Importance, determinants and gender dimensions of forest income in Eastern Highlands of Ethiopia: The case of communities around Jelo Afromontane Forest. Forest Policy and Economics, 28, 1-7. https://doi.org/10.1016/ j.forpol.2013.01.005

Belcher, B., \& Perez, M. R. (2005). Global patterns and trends in the use and management of commercial NTFPs : Implications for livelihoods and conservation. World Development, 33(9), 1435-1452. https://doi.org/ 10.1016/j.worlddev.2004.10.007

Chen, H., Zhu, T., Krott, M., \& Maddox, D. (2013). Community forestry management and livelihood development in Northwest China: Integration of governance, project design, and community participation. Regional Environmental Change, 13, 67-75.https://doi.org/10.1007/s10113-012-0316-3

Dako, F. X., Purwanto, R. H., Faida, L. R. W., \& Sumardi. (2018). Firewood and carpentry wood contribution to the communities of Mutis Timau Protected Forest, Timor Island. Jurnal Manajemen Hutan Tropika, 24, 166-174. https://doi.org/10.7226/jtfm.24.3.166

Dako, F. X., Purwanto, R. H., Faida, L. R. W., \& Sumardi. (2019). Community's social capital in the management of Mutis Timau Protected Forest in Timor Island, Indonesia. Biodiversitas, 20(8), 2177-2186. https://doi.org/10. 13057/biodiv/d200811

Das, N. (2010). Incidence of forest income on reduction of inequality: Evidence from forest dependent households in milieu of joint forest management. Ecological Economics, 69(8), 1617-1625. https://doi.org/10.1016/ j.ecolecon.2010.03.003 
Dewi, I. N., Awang, S. A., Andayani, W., \& Suryanto, P. (2018). Karakteristik petani dan kontribusi hutan kemasyarakatan $(\mathrm{HKm})$ terhadap pendapatan petani di Kulon Progo. Jurnal Ilmu Kehutanan, 12, 86-98.

Diniyati, D., \& Achmad, B. (2015). Kontribusi pendapatan hasil hutan bukan kayu pada usaha hutan rakyat pola agroforestri di Kabupaten Tasikmalaya. Jurnal Ilmu Kehutanan, 9(1).

Jagger, P., Luckert, M. M. K., \& Duchelle, A. M. Y. E. (2014). Tenure and forest income: Observations from a global study on forests and poverty. World Development, 64, S43-S55. https://doi.org/10.1016/j.worlddev.2014. 03.004

Júnior, P. C. B., Guimarães, D. A., \& Pendu, Y. L. (2010). Non-legalized commerce in game meat in the Brazilian Amazon: A case study. International Journal of Tropical Biology and Conservation, 58(3), 1079-1088. https://doi.org/10.15517/rbt.v58i2.5264

Kaoma, H., \& Shackleton, C. M. (2015). The direct-use value of urban tree non-timber forest products to household income in poorer suburbs in South African towns. Forest Policy and Economics, 61, 104-112. https//doi.org/10. 1016/j.forpol.2015.08.005

Kar, S. P., \& Jacobson, M. G. (2012). NTFP income contribution to household economy and related socioeconomic factors: Lessons from Bangladesh. Forest Policy and Economics, 14(1), 136-142. https://doi.org/ 10.1016/j.forpol.2011.08.003

Liu, J., Ouyang, Z., \& Miao, H. (2010). Environmental attitudes of stakeholders and their perceptions regarding protected area-community conflicts: A case study in China. Journal of Environmental Management, 91(11), 2254-2262. https://doi.org/10.1016/j.jenvman.2010. 06.007

Liu, D., Cheng, H., Bussmann, R. W., Guo, Z., Liu, B., \& Long, C. (2018). An ethnobotanical survey of edible fungi in Chuxiong City, Yunnan, China. Journal of Etnobiology and Ethnomedicine, 14(42), 1-10.

Loaiza, T., Nehren, U., \& Gerold, G. (2015). REDD and incentives: An analysis of income generation in forestdependent communities of the Yasuní Biosphere Reserve. Ecuador Applied Geography 62, 225-236. https://doi.org/10.1016/j.apgeog.2015.04.020

Mahapatra, K. A., Tewari, D. D., \& Baboo, B. (2015). Displacement, deprivation and development: The impact of relocation on income and livelihood of tribes in Similipal Tiger and Biosphere Reserve, India. Environmental Management, 56(2), 420-432. https://doi.org/10.1007/s00267-015-0507-z

Mahmood, S., \& Zaleha, M. N. (2013). Human capital inequality and income inequality: Developing countries.
Pertanika Journal Social Sciences and Humanities, 21, 189-200.

Mazunda, J., \& Shively, G. (2015). Measuring the forest and income impacts of forest user group participation under Malawi's forest co-management program. Ecological Economics, 119, 262-273. https://doi.org/10.1016/j.eco lecon.2015.09.016

Mcelwee, P. D. (2010). Resource use among rural agricultural households near protected areas in Vietnam: The social costs of conservation and implications for enforcement. Enviromental Management, 45, 113-131. https://doi.org/10.1007/s00267-009-9394-5

[MoEF] Ministry of Enviroment and Forestry. (2016). Peraturan Menteri Lingkungan Hidup dan Kehutanan Nomor: P.83/MENLHK/SETJEN/KUM.1/10/2016 tentang Perhutanan Sosial. Jakarta: Kementerian Lingkungan Hidup dan Kehutanan.

Morsello, C., Ruiz-Mallen, I., Diaz, M. D. M., \& ReyesGarcia, V. (2012). The effects of processing non-timber forest products and trade partnerships on people's wellbeing and forest conservation in Amazonian societies. Plos One, 7(8). https://doi.org/10.1371/journal.pone. 0043055

Mutenje, M. J., Ortmann, G. F., \& Ferrer, S. R.D. (2011). Extraction of non-timber forest products as a coping strategy for HIV/AIDS-afflicted rural households in South-eastern Zumbabwe. African Journal of AIDS Research, 10(3), 37-41. https://doi.org/10.2989/ 16085906.2011 .626285

Nazir. (2003). Metode penelitian. Jakarta: Ghalia Indonesia Press.

Norini, H., \& Fadli, S. A. (2007). The importance of Ayer Hitam Forest Reserve (AHFR), Puchong, Selangor to the Temuan ethnic subgroup. Pertanika Journal Tropical Science, 30(2), 97-107.

Oli, B. N., Treue, T., \& Smith-Hall, C. (2016). The relative importance of community forests, government forests, and private forests for household-level incomes in the middle hills of Nepal. Forest Policy and Economics, 70, 155-163. https://doi.org/10.1016/j.forpol.2016.06.026

Petriello, M. A., \& Stronza, A. L. (2019). Campesino hunting and conservation in Latin America. Conservation Biology, 34(2), 338-353. https://doi.org/10.1111/cobi. 13396

Rahut, D. B., Ali, A., \& Behera, B. (2015). Household participation and effects of community forest management on income and poverty levels: Empirical evidence from Bhutan. Forest Policy and Economics, 6, 2029. https://doi.org/10.1016/j.forpol.2015.06.006

Roe, J. L., \& Naughton-treves, L. (2014). Effects of a policy- 
induced income shock on forest-dependent households in the Peruvian Amazon. Ecological Economics, 97, 1-9. https://doi.org/10.1016/j.ecolecon.2013.10.017

Senoadji, G. (2009). Kontribusi hutan lindung terhadap pendapatan masyarakat desa di sekitarnya: Studi kasus di Desa Air Lanang Bengkulu. Jurnal Manusia dan Lingkungan, 16(1), 12-22.

Sevilla, C. G., Tuwu A., \& Syah, A. (1993). Pengantar metode penelitian. Jakarta: Universitas Indonesia Press.

Simon, H. (2010). Dinamika hutan rakyat di Indonesia. Yogyakarta: Pustaka Pelajar Press.

Ticktin, T. (2004). The ecological implications of harvesting non-timber forest products. Journal of Applied Ecology, 41, 11-21. https://doi.org/10.1111/j.1365-2664.2004. 00859.x

Turjaman, M., Tamai, Y., Santoso, E., Osaki, M., \& Tawaraya, K. (2006). Arbuscular mycorrhizal fungi increased early growth of two non-timber forest product species Dyera polyphylla and Aquilaria filaria under greenhouse conditions. Mycorrhiza, 16, 459-464. https://doi.org/10.1007/s00572-006-0059-4

Uprety, Y., Poudel, R. C., Gurung, J., Chettri, N., \& Chaudhary, R. P. (2016). Traditional use and management of NTFPs in Kangchenjunga landscape: Implications for conservation and livelihoods. Journal of Ethnobiology and Ethnomedicine, 12(19), 1-59. https://doi.org/10.1186/s13002-016-0089-8

Vedeld, P., Angelsen, A., Bojö, J., Sjaastad, E., \& Kobugabe, G. (2007). Forest environmental incomes and the rural poor. Forest Policy and Economics, 9, 869-879. https://doi.org/10.1016/j.forpol.2006.05.008

Worku, A., Pretzsch, J., Kassa, H., \& Auch, E. (2014). The significance of dry forest income for livelihood resilience: The case of the pastoralists and agropastoralists in the drylands of South Eastern Ethiopia. Forest Policy and Economics, 41, 51-59. https://doi.org/ 10.1016/j.forpol.2014.01.001

Wulandari, C., \& Kurniasih, H. 2019. Community preferences for social forestry facilitation programming in Lampung, Indonesia. Forest and Society, 3, 114-132. 